ARTIKEL PENELITIAN

\title{
FAKTOR YANG BERHUBUNGAN DENGAN SELF EFFICACY DALAM MEMERIKSAKAN KEHAMILAN DI KOTA BALIKPAPAN
}

\author{
Nina Mardiana ${ }^{1)}$, Grace C Sipasulta ${ }^{2)}$, MeittyAlbertina $^{3)}$ \\ ${ }^{12) 3)}$ Program Studi kebidanan Balikpapan, Poltekkes Kemkes Kaltim, Jl. Sorong \\ No 9 RT 081 Balikpapan. \\ Email: ninadisertasi@gmail.com
}

\begin{abstract}
In Indonesia, the utilization of antenatal services by health workers is only $66 \%$ and this figure decreases during childbirth, where the mother who examined her pregnancy to a health worker did not deliver her labor at a health facility, which amounted to $9.12 \%$. This study aims to explain the relationship between knowledge and intention towards self efficacy of pregnant women in antenatal care in Balikpapan City. This type of research is Quasi Experiment Design with pre and post control group study. The study design used Non Equivalent Control Group. Samples were pregnant women with gestational age are entering the second trimester in Balikpapan City who visited twenty women cases and twenty women are control. The results of the study have a significant relationship between knowledge of Self efficacy P value: 0.043, there is a significant relationship between intention to self efficacy P value: 0.029 . The conclusion of this study is that the self efficacy of pregnant women is high, pregnant women are not in high risk age, mothers with high parity and parity are both having high knowledge. There are still pregnant women who have high knowledge but do not have their pregnancies checked on health workers. Most mothers have the intention to have their pregnancies checked on health workers but there are still pregnant women who have their pregnancy checks less than the prescribed standard of at least 4 times during pregnancy.
\end{abstract}

Keywords: Knowledge, Intention, Self efficacy.

Abstrak

Di Indonesia pemanfaatan pelayanan antenatal oleh tenaga kesehatan hanya $66 \%$ dan angka ini menurun saat terjadi persalinan, dimana ibu yang memeriksakan kehamilannya ke tenaga kesehatan tidak melangsungkan persalinannya di fasilitas kesehatan, yaitu sebesar 9,12\%. Penelitian ini bertujuan menjelaskan hubungan pengetahuan dan niat terhadap self efficacy ibu hamil dalam pelayanan antenatal di Kota Balikpapan. Jenis penelitian yang adalah penelitian eksperimen semu (Quasi Experiment Design) dengan pre dan post control group study. Rancangan penelitian menggunakan Non Equivalen Control Group.Sampel adalah ibu hamil dengan usia kehamilan memasuki tri mester II yang berada di Kota Balikpapan yang berkunjung ke puskesmas Muara Rapak sebanyak 20 orang dan kontrol ibu hamil sebanyak 20 orang. Hasil penelitian ada hubungan yang signifikan pengetahuan terhadap Self efficacyp-value : 0,043, ada hubungan yang signifikan niat terhadap self efficacyp-value : 0,029. Kesimpulan pada penelitian ini self efficacy ibu hamil tergolong tinggi, ibu hamil tidak dalam usia risiko tinggi, Ibu dengan paritas tinggi maupun paritas sedang sama-sama memiliki pengetahuan tinggi. Masih ada ibu hamil yang memiliki pengetahuan tinggi tetapi tidak memeriksakan kehamilannya pada tenaga kesehatan. Sebagian besar ibu memiliki niat untuk memeriksakan kehamilannya pada tenaga kesehatan tetapi masih ada ibu hamil yang melakukan pemeriksaaan kehamilannya kurang dari standar yang ditentukan yaitu minimal 4 kali selama kehamilan.

Kata kunci : Pengetahuan, Niat, Self efficacy. 


\section{PENDAHULUAN}

Di Indonesia kesehatan ibu khususnya ibu hamil masih memerlukan perhatian karena masih tingginya angka kematian ibu berkaitan dengan masih belum memadainya cakupan dan kualitas pelayanan kesehatan antenatal. Meskipun angka kematian ibu sudah jauh mengalami penurunan yaitu 228/100.000 kelahiran hidup dari 359/100.000 kelahiran hidup tahun 2003, hal ini terlihat dari jumlah persalinan yang ditolong oleh tenaga kesehatan yang meningkat namun masih jauh dari target MDGs tahun 2015 yaitu 102/100.000 kelahiran hidup (Kementerian Kesehatan RI. 2015)

Penyebabutama kematian antara lain adalah hipertensi dalam kehamilan dan perdarahan post partum. Penyebab ini dapat diminimalisir apabila kualitas pelayanan Antenatal Care dilaksanakan dengan baik. Keadaan di atas menuntut peningkatan pelayanan Kesejahteraan Ibu dan Anak, baik dari segi jangkauan maupun mutu.

Belum meratanya jangkauan dan kualitas pelayanan kesehatan ibu dan anak antara lain keterjangkauan lokasi tempat pelayanan yang lokasinya sulit dicapai oleh para ibu menyebabkan berkurangnya akses ibu hamil terhadap pelayanan kesehatan. Jenis dan kualitaspelayanan yang kurang memadai juga menjadi penyebab rendahnya akses ibu hamil terhadap pelayanan kesehatan berkualitas. Selain itu keterjangkauan terhadap informasi yang kurang menyebabkan juga rendahnya penggunaan pelayanan kesehatan yang tersedia ((Kementerian Kesehatan RI. 2015)

Perawatan kehamilan yang berorientasi pada anjuran dari WHO meliputi minimal pemeriksaan 4 kali selama kehamilan. Pemanfaatan perawatan antenatal di negara berkembang adalah rendah $(65 \%)$ bila di banding dengan negara maju sebesar (97\%) (Dairo M. and KE. 2010). Di Indonesia pemanfaatan pelayanan antenatal (K4) oleh tenaga kesehatan hanya $61,4 \%$.

Faktor yang mempengaruhi penggunaan pelayanan antenatal adalah daerah tempat tinggal (perkotaan atau pedesaan), umur, jumlah kelahiran, tingkat pendidikan, kekayaan atau status ekonomi (WHO, 2015). Hasil penelitian yang dilakukan oleh Ike, 2009 menyatakan bahwa tingkat pendidikan ibu hamil masih berada di tingkat menengah kebawah dan ada hubungan yang signifikan antara tingkat 
pendidikan dengan kunjungan pemeriksaan kehamilan (Ike R. 2009). Begitu juga dengan penelitian yang dilakukan oleh Mardiana mendapatkan $68 \%$ pendidikan ibu hamil di kota Balikpapan berada pada tingkat menengah kebawah (Mardiana N, A, and S. 2014)

Berdasarkan uraian di atas dapat disimpulkan bahwa efikasi diri secara umum keyakinan seseorang mengenai kemampuannya dalam mengatasi beraneka ragam situasi yang muncul dalam hidupnya. Efikasi diri tidak berkaitan dengan kecakapan yang ia miliki seberapa aspek dari kognisi dan perilaku seseorang. Oleh karena itu, perilaku satu individu akan berbeda dengan individu yang lain.

Rendahnya tingkat pendidikan ibu hamil akan berdampak pada rendahnya pengetahuan yang dapat menyebabkan ibu hamil tidak mempunyai keyakinan akan kemampuannya untuk melakukan pemeriksaan kehamilan. Pendidikan dan pengetahuan ibu yang tinggi akan mudah mendapatkan informasi, semakin banyak informasi yang masuk semakin banyak pula pengetahuan yang diperoleh dan kecenderungan untuk menjaga kesehatan juga semakin tinggi (Marullyta and Pudjiraharjo 2013)
Masalah-masalah tersebut dapat diminimalisasikan jika ibu hamil memilki pengetahuan dan kemampuan serta bagaimana efikasi diri yang baik untuk mengelola kesehatan dan kehamilannya. Hasil penelitian (Moeloek 2015) menyatakan semakin tinggi tingkat pendidikan seseorang, maka semakin tinggi self-efficacy yang dimilikinya. Self-efficacy berkaitan dengan keyakinan pribadi seseorang dalam membuat keputusan memilih untuk terlibat atau menolak perilaku positif maupun negatif di sekitarnya. Keyakinan atau kemampuan ibu untuk dapat melakukan suatu pekerjaan atau tindakan tertentu yang akan berpengaruh terhadap kehidupannya dan kehamilannya.

Di Kalimantan Timur, ibu yang memeriksakan kehamilannya pada tenaga kesehatan cukup tinggi untuk kunjungan pertama kehamilan tetapi tidak diikuti dengan kunjungan berikutnya, menurut Profil Kesehatan Prov. Kalimantan Timur tahun 2013 kunjungan pertama berjumlah $97,4 \%$ tetapi kunjungan ke 4 menjadi $85 \%$ (Dinas Kesehatan Provinsi Kaltim 2014)

Berdasarkan permasalahan tersebut, maka akan diteliti hubungan pengetahuan dan niat dengan self efficacy ibu hamil dalam memeriksakan 
kehamilannya pada tenaga kesehatan di kota Balikpapan.

\section{METODE PENELITIAN}

Jenis penelitian yang digunakan adalah eksperimen semu (Quasi Experiment Design) dengan pre dan post control group study. Rancangan penelitian menggunakan Non Equivalen Control Group. Dalam rancangan ini kelompok eksperimen diberikan intervensi penyuluhan tentang antenatal care kemudian dilakukan pre test dan post test, sedangkan pada kelompok kontrol melakukan pemeriksaan kehamilan seperti biasa lalu dilanjutkan dengan post test. Sampel dalam penelitian ini adalah ibu hamil dengan usia kehamilan memasuki tri mester II (4 bulan) yang berada di Kota Balikpapan yang berkunjung ke puskesmas muara Rapak pada bulan Juni - Juli 2015 berjumlah 16 orang kasus dan 16 orang kontrol. Penelitian ini berlokasi di Kota Balikpapan Propinsi Kalimantan Timur, pada bulan Juni - Juli 2015. Teknik pengumpulan data dilakukan dengan cara mengajukan pertanyaan pada responden dengan menggunakan alat pengumpul data berupa lembar pertanyaan yang sudah disiapkan.

\section{HASIL DAN PEMBAHASAN}

1. HASIL

Karakteristik responden

Tabel 1. Karakteristik Responden Berdasarkan Umur Responden, Pendidikan Responden dan Suami, Pekerjaan Responden dan Suami.

\begin{tabular}{lll}
\hline Umur responden & Statistik & \\
\hline Maksimum & 38 & \\
Minimum & 17 & \\
Mean & 24,95 & \\
Median & 25 & Suami \\
\hline Pendidikan & Responden & $1(5 \%)$ \\
\hline Tidak tamat SD & $4(20 \%)$ & $0(0 \%)$ \\
SLTP & $1(5 \%)$ & $13(65 \%)$ \\
SLTA & $7(35 \%)$ & $3(15 \%)$ \\
Diploma & $1(5 \%)$ & $3(15 \%)$ \\
P T & $7(35 \%)$ & Suami \\
\hline Pekerjaan & Responden & $1(5 \%)$ \\
\hline Tidak bekerja & $15(75 \%)$ &
\end{tabular}


Swasta

Wira usaha

$4(20 \%)$

$16(80 \%)$

PNS, ABRI

$0(0 \%)$

$1(5 \%)$

$1(5 \%)$

$2(10 \%)$

Total

$20(100 \%)$

$20(100 \%)$

Hasil penelitian

menunjukkan bahwa dari 20 orang

responden ibu hamil yang diteliti

berdasarkan umur paling muda

berumur 18 tahun dan paling tua

berumur 38 tahun dan rata-rata

berumur 25,5 tahun. Berdasarkan

pendidikan responden sebanyak 4

orang $(20 \%)$ responden tidak

tamat sekolah dasar, sebanyak 7

orang (35\%) tamat SLTA dan

sebanyak 7 orang $(35 \%)$

berpendidikan perguruan tinggi.
Berdasarkan pendidikan suami ada 1 orang (5\%) yang tidak tamat sekolah dasar dan yang terbanyak adalah tamat SLTA sebanyak 13 orang (65\%). Berdasarkan pekerjaan suami responden sebagian besar memiliki pekerjaan swasta 16 orang $(80 \%)$ dan ada 1 orang yang tidak bekerja (5\%). Dan yang berdasarkan pekerjaan responden sebagian besar (75\%) atau 15 orang responden tidak bekerja yang terlihat pada tabel 1 .

\section{Analisis Univariate}

Tabel 2. Distribusi Prekuensi Pengetahuan, Niat dan Self Efficacy Responden Dalam Pelayanan Antenatal.

\begin{tabular}{lc}
\hline Indikator & Prequensi $(\%)$ \\
\hline Pengetahuan & \\
$-\quad$ Tinggi & $12(60 \%)$ \\
$-\quad$ Rendah & $8(40 \%)$ \\
Niat & $16(80 \%)$ \\
$-\quad$ Ada & $4(20)$ \\
- Tidak ada & $12(60 \%)$ \\
Self efficacy & $6(30 \%)$ \\
$-\quad$ Tinggi & $2(10 \%)$ \\
$-\quad$ Sedang & \\
$-\quad$ Rendah & $20(100 \%)$ \\
\hline Jumlah &
\end{tabular}

Berdasarkan hasil penelitian responden memiliki pengetahuan didapatkan bahwa 12 orang $(60 \%)$ tinggi dan $40 \% \quad$ (8) orang 
responden dengan pengetahuan

rendah. $80 \%$ (16) orang responden

memiliki niat untuk memeriksakan

kehamilannya dan sebanyak 18 orang $(90 \%)$ memiliki self efficacy sedang dan tinggi yang terlihat pada tabel 2.

\section{Analisis Bivariat}

Tabel 3. Tabulasi Silang Pengetahuan dan Niat Terhadap Self Efficacy Responden Dalam Pelayanan Antenatal.

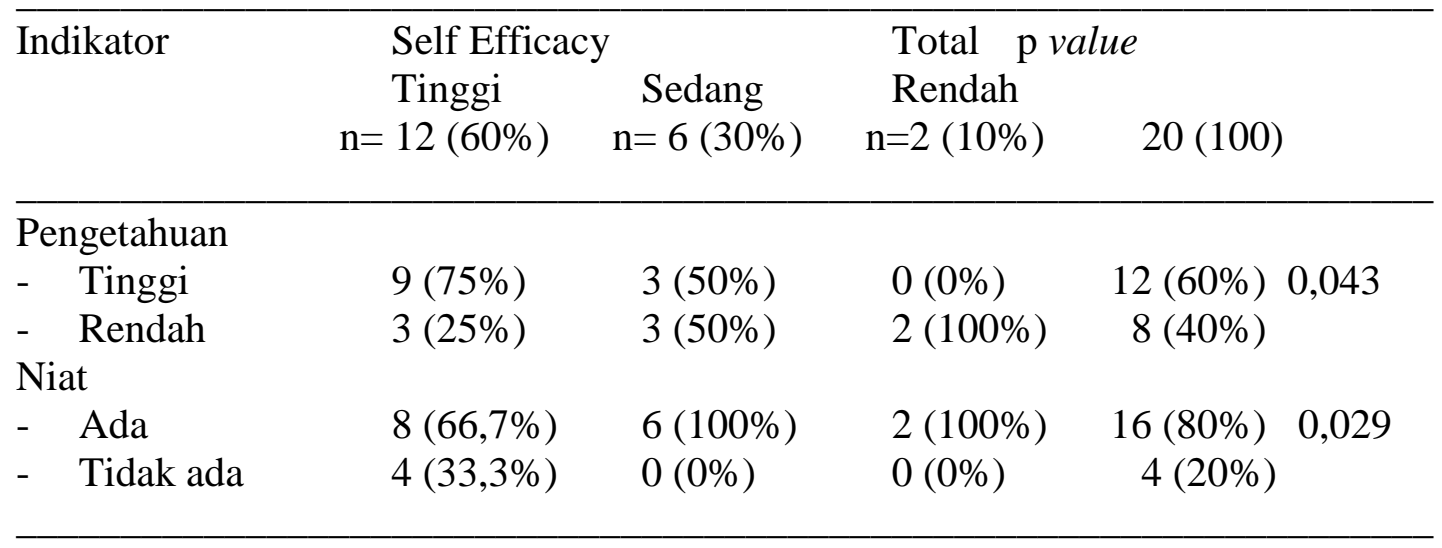

Tabel 4. Tabulasi Silang Pengetahuan dan Niat Responden Dalam Pelayanan Antenatal.

\begin{tabular}{|c|c|c|c|c|}
\hline Indikator & $\begin{array}{c}\text { Niat } \\
\text { Ada } \\
\mathrm{n}=16(80 \%)\end{array}$ & $\begin{array}{l}\text { Tidak ada } \\
\mathrm{n}=4(20 \%)\end{array}$ & $\begin{array}{l}\text { Total } \\
20(100 \%)\end{array}$ & $\mathrm{p}$ value \\
\hline $\begin{array}{ll}\text { Pengetahuan } \\
-\quad \text { Tinggi } \\
-\quad \text { Rendah }\end{array}$ & $\begin{array}{l}12(75 \%) \\
4(25 \%)\end{array}$ & $\begin{array}{l}4(100 \%) \\
0(0 \%)\end{array}$ & $\begin{array}{c}16(80 \%) \\
4(20 \%)\end{array}$ & 0,015 \\
\hline
\end{tabular}

Hasil penelitian menunjukkan sebanyak 8 responden $(40 \%)$ termasuk dalam kategori pengetahuan rendah, 4 responden (20\%) tidak memiliki niat, 12 responden $(60 \%)$ memiliki Self Efficacy tinggi, 6 responden (30\%) termasuk Self Efficacy sedang dan 2 responden $(10 \%)$ memiliki Self Efficacy rendah. Hasil uji antara pengetahuan dan niat terhadap Self Efficacy dengan menggunakan uji regresi metoda enter, diperoleh masing-masing nilai $p$ value $=0,043$ dan 0,029 . Dengan demikian, ada hubungan significan antara pengetahuan dengan Self Efficacy dan ada 
hubungan significan niat dengan

\section{PEMBAHASAN}

Untuk melakukan pelayanan antenatal ibu hamil perlu mengembangkan niat. Selain itu, pengetahuan sangat bermanfaat untuk menerjemahkan niat ini ke dalam aktivitas yang sebenarnya yaitu melakukan pelayanan antenatal. Banyak penelitian telah menemukan bukti untuk klaim pengetahuan yang memperantarai niat dan perilaku, meskipun hasil yang tidak konsisten juga muncul (Norman, P. 2005). Tujuan dari studi ini adalah untuk menganalisis apakah pengetahuan (variabel mediator) memediasi pengaruh niat (independen variabel) pada self efficacy (variabel dependen) Diasumsikan bahwa pengetahuan berpengaruh pada niat, yang secara statistik tercermin oleh interaksi antara pengetahuan dan self-efficacy.

Hipotesis ini sejalan dengan (Bandura 1995) bahwa selfefficacy merupakan prasyarat yang diperlukan untuk proses mediasi diri individu dalam hal ini ibu hamil yang optimis memegang keyakinan tentang kemampuan
Self Efficacy (Tabel 3).

mereka untuk melanjutkan pemeriksaan kehamilan pada tenaga kesehatan. Oleh karena itu, orang dengan self-efficacy tinggi akan lebih mungkin untuk menerjemahkan niat mereka ke dalam tindakan. Dengan kata lain, pengetahuan tidak dapat menerjemahkan niat menjadi perilaku jika ibu hamil tersebut terganggu oleh keraguan diri. Ibu dengan self-efficacy yang rendah tidak mendapatkan manfaat dari pengetahuan, sehingga pengetahuan merupakan strategi yang kuat bagi ibu hamil untuk meyakini bahwa ia bisa mengambil tindakan memeriksakan kehamilannya.

Pengetahuan sangat baik membantu seseorang untuk menerjemahkan niat dalam perilaku atau tindakan dengan self efficacy yang rata-rata tinggi, karena mereka lebih memungkinkan untuk bertindak atas rencana mereka. Sesuai dengan penelitian yang dilakukan oleh Wiedemann at all, 2009 yang menentukan niat sebagai variabel independen dan sebagai moderator 
serta analisisnya juga meniru dua studi terbaru pada aktivitas fisik dan perilaku diet di Jerman, Korea Selatan, dan Kosta Rika yang telah menemukan hasil yang sama (Gutiérrez-Doña et al. 2009). WHO (World Health Organization) dalam (Notoatmodjo 2007) memberikan penjelasan tentang teori bahwa sebuah ilmu kesehatan dapat dijabarkan melalui pengetahuan yang dia didapatkan dari pengalaman. (SF 2015) menjelaskan bahwa pengetahuan seseorang bisa meliputi fakta-fakta berupa kabar dan dari pengalaman ketika individu tersebut menghadapi fenomena yang ada.

Ibu hamil dengan selfefficacy yang rendah akan mengalami kesulitan ketika hendak datang ke pusat pelayanan kesehatan. Sulit untuk mengajarkan pada ibu hamil bagaimana merencanakan perilaku mereka lebih baik atau bagaimana meningkatkan niat mereka. Pertama tama mereka harus mendapatkan kepercayaan diri yang lebih pada sumber daya mereka sendiri untuk mengubah atau mempertahankan gaya hidup sehat bahkan ketika hambatan berlaku (Bandura 1995)

Tingginya self efficacy yang dimiliki oleh responden mungkin disebabkan karena adanya motivasi dalam diri individu tersebut. Hal ini sesuai dengan penelitian yang dilakukan oleh (A.Turner, M., and RW. 2009) terhadap 264 mahasiswa dan ditemukan bahwa motivasi intristik dan self efficacy akan mempengaruhi akademik performan seseorang, dimana seseorang yang yakin akan kemampuan dirinya untuk mencapai prestasi akademik maka individu tersebut akan benar-benar memperoleh keberhasilan dalam akademiknya.

Self efficacy yang tinggi mendorong pembentukan pola pikir untuk mencapai outcome expectancy dan pemikiran untuk mencapai outcome expectancy akan memunculkan outcome expectancy yang nyata, namun hal ini harus didukung dengan goal congruence yang baik (Wiedemann et al. 2009). Pengetahuan dan kepercayaan merupakan komponen yang mendasari pelaksanaan self management individu dan keluarga, 
karena pengetahuan dan kepercayaan memberikan dampak pada perilaku yang lebih spesifik yaitu self efficacy, outcome expectancy dan goal congruence namun pengetahuan tidak mengarah secara langsung kepada perubahan perilaku self management, peningkatan pengetahuan terkait dengan peningkatan perilaku self regulation dan fasilitas sosial (Gutiérrez-Doña et al. 2009). Penelitian menyebutkan bahwa meningkatkan pengetahuan melalui edukasi dapat meningkatkan self efficacy untuk melakukan perubahan perilaku (Aria Wahyuni and Fitrianola Rezkiki 2015)

Bandura adalah tokoh yang memperkenalkan istilah efikasi diri (self-efficacy). Ia mendefenisikan bahwa efikasi dirii adalah keyakinan individu mengenai kemampuan dirinya dalam melakukan tugas atau tindakan yang diperlukan untuk mencapai hasil tertentu. ${ }^{47}$ Sementara itu, Baron dan Byrne (1991) mendefenisikanan efikasi diri sebagai evaluasi seseorang mengenai kemampuan atau kompetensi dirinya untuk melakukan suatu tugas, mencapai tujuan, dan mengatasi hambatan. Bandura dan Woods menjelaskan bahwa efikasi diri mengacu pada keyakinan akan kemampuan individu untuk menggerakkan motivasi, kemampuan kognitif, dan tindakan yang diperlukan untuk memenuhi tuntutan situasi (Wulandari 2000) Meskipun Bandura menganggap bahwa efikasi diri terjadi pada suatu kemampuan fenomena situasi khusus, para peneliti yang lain telah membedakan efikasi diri khusus dari efikasi diri secara umum atau generalized self-efficacy (Gully; R.Hogan, and Robbert 2001) efikasi diri secara umum menggambarkan suatu penilaian dari seberapa baik seseorang dapat melakukan suatu perbuatan pada situasi yang beraneka ragam.

Efikasi diri secara umum berhubungan dengan dengan harga diri atau self-esteem karena keduanya merupakan aspek dari penilaian dari yang berkaitan dengan kesuksesan atau kegagalan seseorang sebagai seorang manusia. Meskipun demikian, keduanya juga memiliki perbedaan, yaitu efikasi diri tidak mempunyai komponen penghargaan diri seperti 
self-esteem. Harga diri ( selfesteem) mungkin suatu sifat yang menyemarakkan; efikasi diri selalu situasi khusus dan hal ini mendahului aksi dengan segera. Sebagai contoh, sesorang bisa memiliki efikasi diri secara umum yang tinggi, dia mungkin menganggap dirinya sanggup dalam banyak situasi. - namun, memiliki harga diri yang rendah karena dia percaya bahwa dia tidak memiliki nilai pokok pada hal yang dikuasai.

$$
\text { Bandura }
$$

mengatakan bahwa efikasi diri pada dasarnya adalah hasil proses kognitif berupa keputusan, keyakinan, atau penghargaan tentang sejauh mana individu memperkirakan kemampuan dirinya dalam melaksanakan tugas atau tindakan tertentu yang diperlukan untuk mencapai hasil yang diinginkan. Menurut dia, efikasi diri tidak berkaitann dengan kecakapan yang dimiliki, tapi berkaitan dengan keyakinan individu mengenai hal apa yang dapat dilakukan dengan kecakapan yang ia miliki seberapa pun besarnya.

Efikasi diri menekankan pada komponen keyakinan diri yang dimiliki seseorang dalam menghadapi situasi yang akan datang yang mengandung kekaburan, tidak dapat diramalkan, dan sering penuh dengan tekanan. Meskipun efikasi diri memiliki suatu pengaruh sebab-musabab yang besar pada tindakan kita, efikasi diri berkombinasi dengan lingkungan, perilaku sebelumnya, dan variabel-variabel personal lainnya, terutama harapan terhadap hasil untuk menghasilkan perilaku. Efikasi diri akan mempengaruhi beberapa aspek dari kognisi dan perilaku seseorang. Gist dan Mitchell mengatakan bahwa efikasi diri dapat membawa pada perilaku yang berbeda di antatara individu dengan kemampuan yang sama karena efikasi diri memengaruhi pilihan, tujuan, pengatasan masalah, dan kegigihan dalam berusaha (Gully;, R.Hogan, and Robbert 2001)

Seseorang dengan efikasi diri percaya bahwa mereka mampu melakukan sesuatu untuk mengubah kejadian-kejadian di sekitarnya, sedangkan seseorang dengan efikasi diri rendah menganggap dirinya pada dasarnya tidak mampu mengerjakan segala sesuatu yang ada disekitarnya. 
Dalam situasi yang sulit, orang dengan efikasi yang rendah cenderung mudah menyerah. Sementara dengan orang dengan efikasi diri yang tinggi akan berusaha lebih keras untuk mengatasi tantangan yang ada (Ghufron M. Nur and S. 2010). Hal senada juga di ungkapkan oleh Gist, yang menunjukkan bukti bahwa perasaan efikasi diri memainkan satu peran penting dalam mengatasi memotivasi pekerja untuk menyelesaikan pekerjaan yang menantang dalam kaitannya dengan pencapaian tujuan tertentu.

Dalam kehidupan seharihari, ibu hamil yang memiliki efikasi diri akan merasakan ketenangan dalam mewujudkan apa yang diinginkannya atau mencapai tujuannya yaitu ingin melahirkan seorang bayi yang mungil dan dalam keadaan sehat dan selamat, sehingga ibu tersebut dengan tenang dan mudah melakukan pemeriksaan kehamilannya tanpa beban. Ketika masalah-masalah muncul, perasaan efikasi diri yang kuat mendorong ibu hamil tersebut untuk tetap tenang dan mencari solusi daripada merenung ketidakmampuannya.
Menurut Bandura (1995) indikator efikasi diri terdiri dari: melihat orang lain, pengalaman, persuasi sosial dan faktor fisiologis yang selanjutnya akan diuraikan secara singkat. Melihat atau mengamati aktivitas seseorang secara berulang-ulang akan memudahkan kita untuk melakukan pekerjaan yang sama seperti yang pernah kita lihat dilakukannya (Modelling).

Bandura (1995) proses demikian ini lebih efektif ketika seseorang melihat dirinya sama dengan model atau yang menjadi modelnya. Jika suatu model yang dirasa seperti dirinya memiliki kemampuan yang sama dan berhasil, hal ini akan meingkatkan efikasidiri si pemodel. Walaupun bukan sebagai hal yang berpengaruh seperti pengalaman masa lalu. Modelling adalah suatu pengaruh kuat ketika seseorang sama sekali tidak percaya atas kekuatan dirinya sendiri.

Tingginya tingkat pengetahuan yang dimiliki oleh ibu hamil sebagai responden dalam penelitian ini juga disebabkan karena faktor pembelajaran individu di lingkungan disekitarnya dan dilingkungan keluarganya yang 
selalu memeriksakan kehamilannya pada tenaga kesehatan. Hal ini dapat membuat ibu hamil mengikuti hal hal yang baik dan merasa yakin bahwa dia mampu dan sanggup melakukan pemeriksaan kehamilan dengan baik sesuai standar yang ditentukan, ini ditunjang oleh latar belakang pendidikan responden sebagian besar (75\%) berpendidikan menengah ke atas. Pendidikan yang tinggi dan pengetahuan yang baik akan memudahkan responden dalam menyerap informasi dan menganalisisnya.

Pengetahuan itu sendiri menekankan pada proses mental dalam mengingat dan mengungkapkan kembali informasi-informasi yang telah diperolehnya secara tepat sesuai dengan apa yang telah mereka peroleh sebelumnya. Ibu hamil tidak hanya dituntut untuk memiliki pengetahuan teknis tentang kehamilannya tetapi juga mempunyai self-efficacy yang baik dan kuat untuk mampu mencapai hasil dari kehamilan yang diinginkannya. Self-efficacy itu sendiri merupakan keyakinan dan harapan mengenai kemampuan untuk menghadapi kegiatan memeriksakan kehamilannya sampai ia melahirkan nanti.

Diketahui bahwa pengetahuan adalah salah satu faktor dari proses terbentuknya efikasi diri. Pengetahuan sebagai dasar individu untuk menentukan sikap dan perilakunya. Pengetahuan sendiri dipengaruhi oleh pendidikan, pekerjaan, umur, pengalaman, dan informasi.

\section{SIMPULAN}

Penelitian ini memberikan gambaran bahwa self Efficacy ibu hamil Berdasarkan hasil penelitian didapatkan bahwa 12 orang (60\%) responden memiliki pengetahuan tinggi dan $40 \%$ (8) orang responden dengan pengetahuan rendah. $80 \%$ (16) orang responden memiliki niat untuk memeriksakan kehamilannya dan sebanyak 18 orang (90\%) memiliki self efficacy sedang dan tinggi. Hasil uji antara pengetahuan dan niat terhadap Self Efficacy dengan menggunakan uji regresi metoda enter, diperoleh masingmasing nilai $p$ value $=0,043$ dan 0 , 029. Dengan demikian, ada hubungan significan antara pengetahuan dengan Self Efficacy dan ada hubungan significan niat dengan Self Efficacy. 
Dengan demikian hipotesis dalam penelitian ini diterima.

\section{UCAPAN TERIMA KASIH}

Ucapan terima kasih ini di berikan

penulis kepada :

1) Direktur Politeknik Kesehatan Kalimantan Timur yang telah memberikan bantuan dana dalam penelitian ini;

2) Pemerintah Kotra Balikpapan, Kecamatan dan Dinas Kesehatan Kota Balikpapan yang telah memberikan rekomendasi dan izin kepada peneliti untuk melaksanakan penelitian.

\section{DAFTAR PUSTAKA}

A.Turner, E., Chandler M., and Heffer RW. 2009. "The Influence of Parenting Styles, Achievement Motivaton and Self-Efficacy on Academic Performan-Ce in College Student." Jounal Coll Student Dev. 50(3337-346).

Aria Wahyuni, and Fitrianola Rezkiki. 2015. "MELALUI EDUKASI KESEHATAN TERSTRUKTUR PENDAHULUAN Ketidakmampuan Jantung Dalam Melakukan Fungsinya Akan Menimbulkan Kerusakan Dan Kerusakan Tersebut Memicu Berbagai Macam Penyakit Jantung
Salah Satunya Penyakit Jantung Koroner ( PJK ). Di Amerika PJK Dipe." JURNAL IPTEKS TERAPAN 9(iL): 28-39.

Bandura, Albert. 1995. Self Efficacy in Changing Societi. U S A: Cmbridge University Press.

Dairo M., and Owoyokun KE. 2010. "Factors Affecting the Utilization of Antenatal Care Services in Ibadan, Nigeria.” 12(1).

Dinas Kesehatan Provinsi Kaltim. 2014. Profil Kesehatan Prov. Kalimantan Timur Tahun 2013. Samarinda: Dinas Kesehatan Provinsi Kaliman Timur.

Ghufron M. Nur, and Risnawati Rini S. 2010. Teori-Teori Psikologi. Jogjakarta: Ar-Ruzz Media. Jakarta.

Gully;, Chen dan, Gist;Gist dan Mitchel dalam R.Hogan, and B.W Robbert. 2001. Personality Psychology: In the Workplace. Washington DC: American Psychology Association.

Gutiérrez-Doña, B. et al. 2009. "How Selfefficacy and Planning Predict Dietary Behaviors in Costa Rican and South Korean Women: A Moderated Mediation Analysis." Appl Psychol 
Mahakam Midwifery Journal, Vol 2, No. 4, November 2018 : 277-291

Heal Well-Being,. 1: 91-104.

Ike R. 2009. "Faktor-Faktor Yang Berhubungan Dengan Pemeriksaan Kunjungan Kehamilan (K4) Di Wilayah Kerja Puskesmas Margorejo Kabupaten Pati Tahun 2009.”

Kementerian Kesehatan RI. 2015. Keputusan Menteri Kesehatan Republik Indonesia Tentang Rencana Strategis Kementerian Kesehatan Tahun 2015-2019. Jakarta.

Mardiana N, Wibowo A, and Supriyanto S. 2014. "Predisposing Factors of The Utilization of Antenatal Care (ANC) and Delivery Based on Customer Driven." Sciknow Publ Ltd Heal Care. 2(4): 59-64.

Marullyta, Astari, and Widodo J Pudjiraharjo. 2013. "Purchase Decision K4 By Pregnant Women in the Work Area Health Centers." Indonesian Health Administration 1(2): 108-19.

Moeloek, Nila F. 2015. "Pembangunan Kesehatan Menuju Indonesia Sehat. In: Rapat Kerja Kesehatan Nasional
Regional Tengah.” In Denpasar Indonesia.

Norman, P., and Conner M. 2005. "The Theory of Planned Behavior and Exercise: Evidence for the Mediating and Moderating Roles of Planning on Intention-Behavior Relationships." $J$ port Exerc Psychol. 27: 488-504.

Notoatmodjo, S. 2007. Promosi Kesehatan Dan Ilmu Perilaku. Jakarta: Rineka Cipta.

SF, Yusuf. 2015. Metodologi Penelitian Kesehatan. Padangsidimpuan: Darmais Press.

Wiedemann, A.U. et al. 2009. "Disentangling the Relation between Intentions, Planning, and Behaviour: A Moderated Mediation Analysis." Psychol Heal. 24: 67-79.

Wulandari, N W. 2000. "Hubungan Antara Efikasi Diri Dan Dukungan Sosial Dengan Kepuasan Kerja”, Skripsi, (Tidak Diterbitkan), (Jogjakarta: Fakultas Psikologi UGM, 2000).” 
Mahakam Midwifery Journal, Vol 2, No. 4, November 2018 : 277-291 